\title{
Leaf Epidermal Studies in Some Araceae
}

\author{
Nandkishor S. Zade \\ Department of Environmental Science, Late Panchfulabai Pawade Arts and Commerce \\ Mahila Mahavidyalaya, Warud-444906, Dist, Amravati (M.S.)
}

\begin{abstract}
Investigations on the epidermal morphology, stomatal ontogeny of the members of Araceae, bring out, Foliar epidermal structure of 16 species of aroids is described. The epidermal cells are mostly isodiametric and polygonal, occasionally undulated or wavy with thick or thin anticlinal walls arranged irregularly or in vertical rows. Leaves are hypostomatic to amphistomatic. Stomatal type is paracytic to tetracytic, stomatal development is perigenous.
\end{abstract}

Keywords: Araceae- Leaf epidermis- Stomata; perigenous development.

\section{Introduction}

The family Araceae, comprised of about 110 genera and 1800 species is mainly tropical and subtropical in distribution (Cronquist 1981). In India, it is represented by about 1000 species belonging to 100 genera. To brief review of literature reveals that this family is extensively studied in regard to few species. However, no comprehensive work on the vegetative anatomy of this family has been undertaken so far.

Anatomical studies have been found to be useful in phylogenetic considerations. Early literature on the stomata chiefly of Webber, 1960, Shah and Gopal 1969, Later on Trivedi and Upadhaya, 1984, studied epidermal structure in the Dieffenbachia spp.

\section{Materials and Methods}

Materials of 12 genera and 16 species of Araceae have been collected for the present investigation. The peels for stomatal and epidermal studies were taken from fresh and fixed material (in 1:3, acetic-ethanol), Epidermal peels were stained in safranine (1\%) and mounted in glycerine. Stomatal ontogeny was studied from temporary acetocarmine (1\%) mounts of epidermal peels of young leaves. The stomatal frequency and index have been calculated according to Metcalfe (1971).

$\frac{S}{E+S} \times \frac{100}{1}$ Stomatal index (SI)

Where $\mathrm{S}=$ number of stomata for unit area, $\mathrm{E}=$ number of epidermal cells in the same area

All microscopic measurements were made with the aid of an occular micrometer.

\section{Observations}

\section{Epidermal Peels}

The cells of the adaxial epidermis are isodiametric and polygonal with straight walls except in the coastal regions where they are narrow, elongated parallel to the veins and in rows. The cells in Aglaonema commutatum and Dieffenbachia picta are with undulated walls.

The cells of the abaxial epidermis are isodiametric and polygonal with straight walls except in Amorphophallus. sylvaticus and Sauromatum pedatum. Where they are irregularly wavy or slightly undulated. In Acorus calamus both the epidermal surfaces have the cells arranged in almost linear rows. Those of the lower surfaces are comparatively narrower.

\section{Stomata}

The leaves of Dieffenbachia picta, Amorphophallus bulbifer, and Sauromatum pedatum. are hypostomatic while those of the other plants are amphistomatic. The number of stomata on the upper surfaces is very few, if at all and distributed near the veins. Materially, the leaf is hypostomatic, although morphologically it is amphistomatic. Anthurium bakeri, Alocasia, Theriophonum and Epipremnum do have few stomata on the upper surface.

The stomata occuring in the laminae of the investigated members of Araceae are irregularly distributed in the inter coastal regions or areas as well as along the minor veins. The number of stomata on the adaxial surface as well as on abaxial surface varies. (Table, 1 )

The stomata are elliptic, oval or rounded in shape. The guard cells are reniform or elongated the size of the stomata varies within the expans of leaf surface on abaxial or adaxial (fig. 1). The stomatal index on the abaxial surface varies from $4.7 \mathrm{u}$ in Acorus calamus to $20.5 \mathrm{u}$ in the Sauromatum pedatum. The stomatal index on the adaxial surface varies from $0.79 u$ in Syngonium auritum to $6.6 \mathrm{u}$ in Theriophonum minutum. (Table-1)

\section{Stomatal Types}

The following different types of stomata are observed.

Paracytic :- It is type of stoma has two subsidiary cells parallel to the guard cells as in Amorphophallus sylvaticus and A. bulbifer, Theriophonum, Sauromatum pedatum, Acorus calamus. (Fig-1 A)

i) Tetracytic:- This is of stoma has two polar and two lateral subsidiary cells generally in one cycle. Besides these they usually have two equally marked lateral encircling cells. placed paralled to the two lateral subsidiaries so that the stomata in these forms are tetracytic and partly amphicyclic as observed in Anthurium regale, Dieffenbachia picta, Scindapsus pictus and Pothos scandens. (Fig-1) 


\section{International Journal of Science and Research (IJSR) \\ ISSN (Online): 2319-7064 \\ Index Copernicus Value (2013): 6.14 | Impact Factor (2014): 5.611}

Development of stomata has been worked out in some of the present plants, the ontogeny is perigenous. Individual protodermal elements here and there divide unequally and cut off a small triangular or rectangular cells in a corner and a large flat cell. Resulting in formation of guard cells and subsidiary cells, later on give rise to tetracytic or amphicyclic stomata.

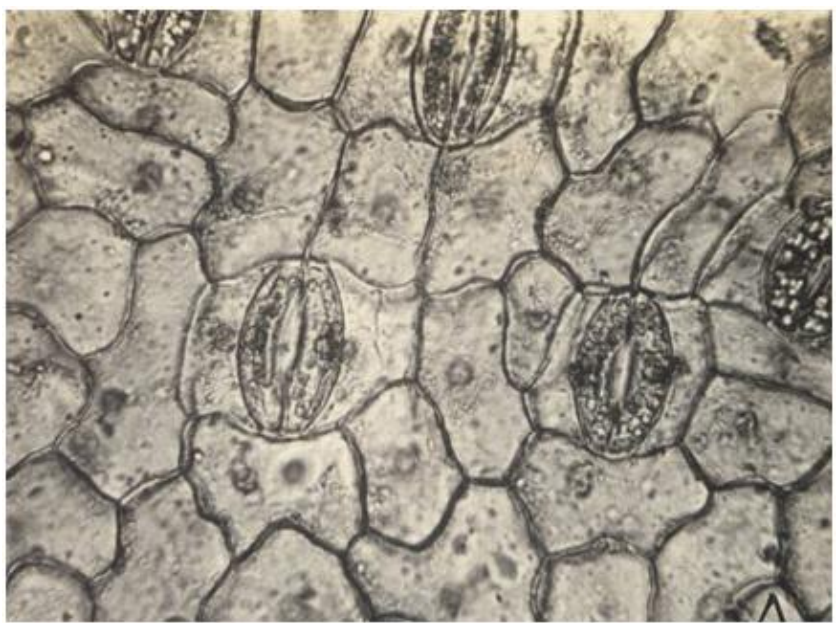

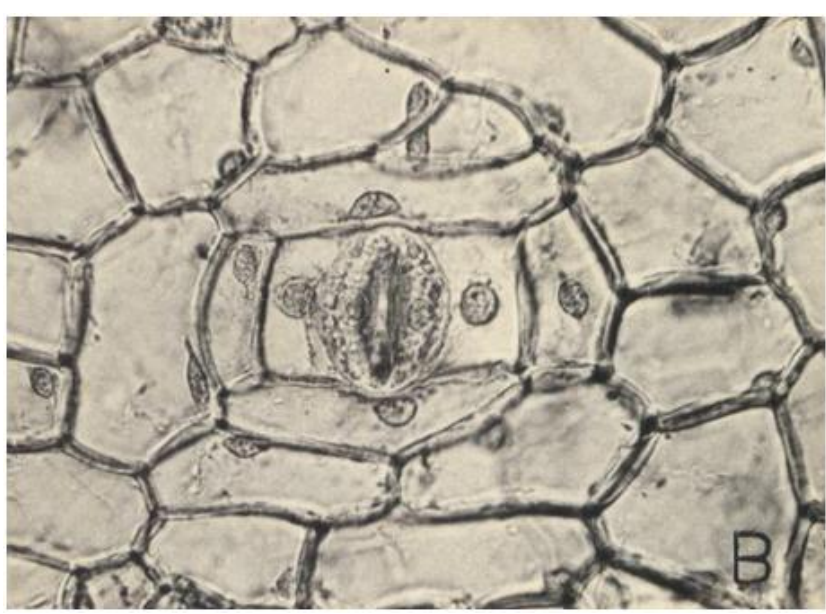

Figure 1 B: Abaxial leaf epidermis of Anthurium acaule

Figure 1A: Abaxial leaf epidermis of Sauromatum pedatum

Table 1: Showing the Stomatal Frequency and Stomatal Index of Epidermal cells

\begin{tabular}{|c|c|c|c|c|c|c|c|}
\hline \multirow{3}{*}{\multicolumn{2}{|c|}{ Name of the plants }} & \multicolumn{2}{|c|}{$\begin{array}{c}\text { Average size of guard } \\
\text { cells in microns } \\
\text { (Abaxial) }\end{array}$} & \multirow{2}{*}{\multicolumn{2}{|c|}{$\begin{array}{c}\text { Stomatal Frequency } \\
\text { Abaxial Epidermis }\end{array}$}} & \multicolumn{2}{|c|}{ Stomatal Index } \\
\hline & & \multirow{2}{*}{ Length } & \multirow{2}{*}{ Breadth } & & & \multirow[t]{2}{*}{$\begin{array}{c}\text { Adaxial } \\
\text { epidermis }\end{array}$} & \multirow[t]{2}{*}{$\begin{array}{l}\text { Abaxial } \\
\text { epidermis }\end{array}$} \\
\hline & & & & Range per mm2 & Average Per mm2 & & \\
\hline 1 & Acorus calamus & 28.8 & 19.2 & $17-33$ & 26 & 4.5 & 4.7 \\
\hline 2 & Anthurium acaule & 48 & 33.6 & $33-57$ & 46 & 1.15 & 6.36 \\
\hline 3 & Anthurium bakeri & 72 & 43.2 & $40-60$ & 49.6 & 5.1 & 7.1 \\
\hline 4 & Anthurium regale & 62.4 & 43.2 & $47-57$ & 49.6 & 1.1 & 9.0 \\
\hline 5 & Anthurium digitatum & 43.2 & 38.4 & $23-37$ & 30.6 & 1.53 & 8.13 \\
\hline 6 & Pothos scandens & 33.6 & 19.2 & $80-97$ & 87.1 & 1.5 & 5.8 \\
\hline 7 & Epipremnum mirabile & 38.4 & 28.8 & $33-40$ & 36.6 & 3.12 & 5.09 \\
\hline 8 & Scindapsus pictus & 57.6 & 38.4 & $10-27$ & 20.3 & 2.0 & 5.76 \\
\hline 9 & Aglaonema commutatum & 72 & 48 & $20-30$ & 26 & 1.2 & 9.67 \\
\hline 10 & Diefffenbachia picta & 84.9 & 52.8 & $13-20$ & 16 & - & 10.9 \\
\hline 11 & Alocasia macrorrhiza & 48 & 28.8 & $133-170$ & 154 & 4.60 & 10.34 \\
\hline 12 & Syngonium auritum & 28.8 & 19.2 & $83.3-116.6$ & 97.3 & 0.79 & 7.04 \\
\hline 13 & Amorphophallus bulbifer & 48 & 28.8 & $83.3-100$ & 89.96 & - & 8.8 \\
\hline 14 & Amorphophallus sylvaticus & 48 & 28.8 & $80-100$ & 92.7 & 2.43 & 14.28 \\
\hline 15 & Theriophonum minutum & 48 & 28.8 & $100-130$ & 116.6 & 6.6 & 16.6 \\
\hline 16 & Sauromatum pedatum & 43.2 & 24 & $207-217$ & 211 & - & 20.5 \\
\hline
\end{tabular}

\section{Discussion and Conclusions}

The epidermal cells are mostly isodiametric and polygonal, occasionally, they may be unduluted or wavy, e.g. Aglaonema commutatum, Dieffenbachia picta, Sauromatum pedatum and Amorphophallus sylvaticus. It is interesting to note that epidermal cells in the last species are undulated, while another species of the same genus. (A. bulbifer), has the walls straight. The striations of the cuticle which are in rings in the epidermal cells in Amorphophallus sylvaticus, demonstrate a characteristic arrangement recalling the distribution of iron fillings in a magnetic field. Pant and Kidwai, 1966 records cutin folds over subsidiary and encircling.
The distribution of stomata is interesting inspite of the fact that the leaf is dorsiventral it is mostly amphistomatic. The distribution of the stomata on the upper surface by and large is fewer. The distribution has to be directly correlated with the trend in conservation of water. One may say that the aroid genera studied demostrate a fundamental tendency towards attainment of hypostomaty which is apparently a derived condition. (Zade, 1986).

In development, the stomata are typically perigenous. The variations in the number of subsidiary cells is on account of variation in division of the neighbouring cells of guard cells, mother cells resulting in tetracytic, paracytic and amphicylic stomatal complex. 
The stomatal complex is sometimes employed as a parameter of taxonomic distinctiveness especially amongst general (c.f. Tomlinson, 1969). Within the present plants it is characteristic of Acorus and Amorphophallus spp, Theriophonum and Sauromatum and Caladium.

The leaf epidermal characters are of taxonomic significance in the members of Araceae with this they can be separated and distinguished based on their stomata, epidermal cells, as these features which are being influenced by enviornmental factors are present on almost every leaf surface.

\section{References}

[1] Cronquist A., 1981 An integrated system of classification of flowering plants, Columbia University Press, New York.

[2] Metcalfe, C.R., 1971: Anatomy of the Monocotyledons, Vol. I Graminineae, Oxford, University Press, London.

[3] Pant D.D. and Kidwai, P. 1966: Structure of leaves and stomatal ontogeny in some Pandanales and Spathiflorae.Senk biol., 47:309-333,

[4] Shah G.L. and Gopal B.V. 1969: Observation on the stomata and their ontogeny in some monocots, seminar on Morphology, Anatomy and Embryology of Land Plants, University of Delhi, P.P. 55-57.

[5] Stebbins G.L. and Khush G.S. 1961: Variation in the organization of the stomatal complex in the leaf epidermis of monocotyledons and its bearing on their phylogeny, Amer. J. Bot. 48: 51-59.

[6] Tomlinson P.B. 1969: Anatomy of the MonocotyledonsIII Commelinales- Zingiberales (ed. C.R. Metcalfe), Clarendon Press, Oxford.

[7] Trivedi B.S. and Upadhaya N. 1984: Epidermal structure of Araceae-I. Dieffenbachia, Schott, Geophytology, 14:143-155.

[8] Zade N.S. 1986: Morphological studies in the monocotyledons-IX Ph.D. Thesis, Marathwada University, Aurangabad.

\section{Author Profile}

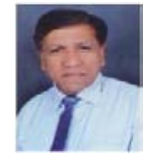

Dr. Nandkishor S. Zade is presently working as Principal of Late Panchfulabai Pawade Arts and commerce women's college, Warud, Dist. Amravati. He has teaching experience of 30 years. He has published 35 research papers in national and international journals/confernces/proceedings etc. $\mathrm{He}$ has successfully completed research projects on 'conservation and cultivation of medicinal plants from Melghat areas' and 'Ethnomedicinal studies and conservation of native genetic resources of Satpura Ranges'. He has guided M.Phil and Ph.D research scholars for dissertation work. He is Honorary forest Taxonamists of East Melghat forest circle of Govt. of Maharashtra and ex-member of board of studies in Botany of S.G.B. Amravati University Amravati. He has worked as organizing secretary of state level seminar U.G.C. sponsored on recent advances in ethno-botany held at Shri Shivaji College, Akot. He is life member of Indian Science Congress Association, Kolkatta and Botanical Association of Amravati University Amravati. 